\title{
Modeling Islamic Economics and Finance Research: A Bibliometric Analysis ${ }^{1}$
}

\author{
Aam Slamet Rusydiana \\ Sharia Economics Applied Research \& Training (SMART), Indonesia \\ Corresponding email:aamsmart@gmail.com \\ Yulizar Djamaluddin Sanrego \\ University of Darussalam Gontor, Indonesia, senapatie@gmail.com \\ Solihah Sari Rahayu \\ UIN Bandung, Indonesia, solihah.sr@gmail.com.
}

Article History

Received: June $6^{\text {th }}, 2020$ Revised: $15^{\text {th }}$ July, 2020 Accepted: January $21^{\text {st }}, 2021$

\begin{abstract}
This study aims to determine the development map of mathematic model in islamic economics and finance research that is indexed by Scopus and other reputable journal with the keyword "Mathematic model in islamic economics and finance". The data analyzed were 100 selected publications. The development map of mathematic model in islamic economics and finance research analyzed using the VOSviewer application program to find out the bibliometric map. The results showed that the number of publications on the development of mathematic model in islamic economics and finance research indexed Scopus from 19832019 experienced a significant increase and the most were published in Journal of King Abdulaziz University: Islamic Economics. Network visualization showed that the map of the development of mathematic model in islamic economics and finance research was divided into 3 clusters. The majority of research is related to modeling of Profit Loss Sharing (PLS) schemes. However, despite the development of using mathematical model in those researches, the approach tends to be adaptive (inductive) from conventional models that already exist. A challenge to review the mainstream model need to be further critically reviewed. Hence, it is necessary for researcher to formulate a mathematical model with a deductive approach that is reduced from Islamic norms or ethics derived from the Alquran and Sunnah.
\end{abstract}

Keywords : Mathematical Model; Islamic Economics; Islamic Finance; Bibliometric JEL Classification: C02; C18

Type of paper: Research Paper

@ IJIEF 2021 published by Universitas Muhammadiyah Yogyakarta, Indonesia All rights reserved

DOI:

https://doi.org/10.18196/ijief.v4i1.8966
Web:

https://journal.umy.ac.id/index.php/ijief/article/view/8966

Citation:

Rusydiana, A. S., Sanrego, Y, D., \& Rahayu, S. S. (2021) Modeling Islamic Economics and Finance Research: A Bibliometric Analysis. International Journal of Islamic Economics and Finance (IIIEF), 4(1), 149-176. DOI: https://doi.org/10.18196/ijief.v4i1.8966.

\footnotetext{
${ }^{1}$ The authors thank to Widya Syafitri from IPB University for the collection and analysis of data.
} 
Rusydiana, Sanrego, \& Rahayu $\mid$ Modeling Islamic Economics and Finance Research: A Bibliometric Analysis

\section{Introduction}

\subsection{Background}

Currently the Islamic financial economy is experiencing euphoria, both in developing countries, or even in developed countries. The financial industry and other forms of Islamic economic institutions are growing throughout the universe, from the Middle East, the Asian region to Western countries such as the United Kingdom. The growth of the Islamic finance industry must be supported by economic development and Islamic finance in theory. The practice and theory of Islamic economics and finance must go hand in hand so that a practical-implementative manifests itself from the application of science at the theoretical-level. Based on this argument, researches on the development of Islamic economic knowledge are very important.

In terms of Islamic economic and financial development that is academictheoretical, Islam has its own paradigm, namely an approach through Islamic economic experiences (behavior) in the past to study the current hot issues that are happening in the field. Then the problem is analyzed with a contemporary economic approach with modern analytical tools that will produce postulates, axioms and Islamic economic theory as a result of empirical experience. Theory testing is done to find the deficiencies of the theory so that it can be evaluated so that the Islamic economic theory model obtained can be better and relatively applicable in many places and times. Among these processes there is the role of mathematical modeling that can be used for testing calculations and describing economic assumptions.

Mathematical modeling in Islamic economics and finance is a mathematical application consisting of real or complex numbers, vectors, matrices, symbols, mathematical operations, and others that form a model that can explain the conditions of an Islamic economic and financial problem (Mirakhor \& Krinchene, 2014). Then in the perspective of Islamic economics and finance, students or professionals need the ability to calculate mathematics and statistics used to complete tasks both in financial institutions and nonfinancial institutions. Without calculation skills, students and professionals will not be able to manipulate economic and financial data.

Financial institutions such as pension fund institutions, securities companies, insurance companies, and asset management companies that require actuarial knowledge, investment modeling, and risk management. Professionals may be quite satisfied with the standards provided by their company and the software used to process data and complete calculation tasks plus the availability of the internet which makes it easy to obtain calculation results quickly and easily. However, it is very important to understand the theory underlying mathematical calculation procedures. Then the development of mathematics and modeling has progressed and even 
Rusydiana, Sanrego, \& Rahayu $\mid$ Modeling Islamic Economics and Finance Research: A Bibliometric Analysis

training on the application of mathematical models has been done, but unfortunately not many applications of mathematical modeling on topics relevant to Islamic economics and finance. From this background, the authors are interested in discussing the development of the application of mathematical models in Islamic economic and financial research that has been indexed by Scopus and other reputable journal since 1983 with 100 publications. So far, there is still very little or even no research that maps research and studies related to the use of mathematical models in research on Islamic economics and finance. Therefore, this study becomes important to do to fill the research gap.

\subsection{Objectives}

This study aims to determine the map of research developments related to the application of mathematical models in Islamic economic and financial research that are indexed by Scopus using the help of VOSviewer software. This analysis is called bibliometric analysis. In addition, prior to bibliometric analysis, publications related to mathematical models in Islamic economic and financial research that were indexed by Scopus were analyzed based on text mining, namely Meta Analysis. Matters presented in the meta-analysis are related to publication, year of publication, country case studies, number of article authors, research topics, citations, and methodological approaches used by each Scopus indexed publication paper related to the application of mathematical models in Islamic economic and financial research.

\section{Literature Review}

In general, the notion of a model is an attempt to create a replica or imitation of a social phenomenon or natural event. There are three types of models namely physical models, anological models and mathematical models. Physical modeling is used to simulate the space or domain in which the phenomenon occurs while anological modeling is carried out by analogizing phenomena with other phenomena to then construct the physical model. The replica of mathematical model is implemented by describing phenomena in a set of equations. The suitability of the model for the phenomenon depends on the accuracy of the formulation of mathematical equations in describing the phenomena that are imitated (Luknanto, 2003).

Mikrakhor and Krinchene (2014) explain a model that presents a theory and simplifies the situation that occurs in the field by describing it into an equation. It is written in the form of formulas that are compared with the explanation of the description of long words. Economics is closely related to the use of mathematical functions and models. Some examples of important 
Rusydiana, Sanrego, \& Rahayu Modeling Islamic Economics and Finance Research: A Bibliometric Analysis

and often used functions are demand and supply functions, budget functions, production possibilities curve functions, production functions, and other economic functions.

Another aim of mathematical approach is to derive a set of conclusions or theorems from a given set of assumptions or postulates Chiang (2005). Instead, any worldviews where set of assumptions or postulates as a point of embarkation should be critically reviewed. In this context, economics is instilled by values which is derived from a certain worldview. In other words, the normative values/ethics which are derived from a particular worldview will come up with theoretical differences, including mathematical model. Mathematical model which derived from Western worldview will certainly claimed that economics shall be positive science devoid of value judgment.

Unfortunately, there are many researches in Islamic economic and financial are still working on conventional mathematical model. The model that presents a theory is mainly developed within the framework of Western worldview. There is a tendency for the scientification process of economics based on secular values to eliminate the vision or purpose of life of a Muslim.

Al-Attas (1995) asserts that the stage of islamization is a solution to organize science to fit the moral message of the Qur'an which does not recognize dichotomy. Islamic economics will not provide a conventional dichotomic customary space between substantive and normative descriptions in social science (Abusaud 1993). Because consideration to make ethics or morals into endogenous variables in a socio-economic system becomes a necessity (Choudhury 1990). Al-Attas's (2014) method of Islamization of Knowledge consists of two steps. First, is to carry out the stage of isolation or elimination of foreign elements and key concepts from the body of existing knowledge, and second, to infuse Islamic values and key concepts into it.

However, Islamic economics methodology (including the usage of mathematical model) should not start from scratch but use the relatively more advanced development in conventional economics (theories and methodologies) and attempt to make them compatible with Islamic economics (Hasan, 2016; Haneef \& Furqani, 2012). Therefore, apart from the beneficial usage of mathematical model, the current working researches shouldn't just purely adopt or a mere infusing the Islamic values into the mainstream's model. What really matter for adopting mathematical models into the Islamic economics is that, it shouldn't cause obstacles in achieving the aim of Islamic economics, which is Falah (Abdullahi, 2018).

Bibliometric mapping is an important research topic in literature studies. Two aspects of bibliometrics which will be distinguished are the development of the bibliometric map and therefore the graphical illustration of the map. Bibliometrics is used as a methodology in many fields of science, first and 
Rusydiana, Sanrego, \& Rahayu $\mid$ Modeling Islamic Economics and Finance Research: A Bibliometric Analysis

foremost for publication patterns in different scientific disciplines. For several decades bibliometrics has provided advantages in management science for making decisions. The use of bibliometrics is a quantitative and statistical analysis to describe patterns of publications without involving segments or describing patterns from publications or entire sections of literature. Researchers can use the bibliometrics method in evaluations to determine the influence of a single author or to describe the relationship between two or more authors.

Van Eck \& Waltman (2007b) stated that bibliometrics is a study of the production and dissemination of information which is operationally reviewed through the production and dissemination of media that records information to be stored and disseminated. Some previous studies related to Islamic economics and finance using this method include research conducted by Rahman et al. (2020) related to SRI sukuk, Ahmid \& Ondes (2019) on PhD research on the theme of Islamic banking and finance in the UK, and Rehman \& Othman (1994) related to Islamic economic literature in general.

\section{Methodology}

This study uses international publication data on the application of mathematical models in Islamic economic and financial research sourced from the Scopus database. Collecting data through publications on Scopus with the Mathematic model in Islamic economics and finance keywords with the categories article titles, abstracts, keywords in the period 1983 - 2019. From the search results obtained as many as 100 publication articles. Data in the form of publications, years of publication, country case studies, number of article authors, research topics, citations, and methodological approaches used by each publication article were analyzed using Microsoft Excel 2010. Whereas the development trends of mathematical model publications in Islamic economic and financial research analyzed using VOSviewer software.

To create maps, VOSviewer uses VOS mapping techniques (Van Eck and Waltman 2007a), where VOS stands for visualization of similarity. VOSviewer can display maps that are built using appropriate mapping techniques. Therefore, this program can be used not only to display maps built using VOS mapping techniques but also to display maps constructed using techniques such as multidimensional scaling. VOSviewer runs on a large number of hardware and operating system platforms and can be started directly from the internet like Web of Science or Scopus database.

The purpose of VOS is to place items in low dimensions such that the distance between the two items accurately reflects the uniformity or interrelation of the items. For each pair of items $i$ and $j$, VOS requires an input similarity $s_{i j}\left(s_{i j}\right.$ 
Rusydiana, Sanrego, \& Rahayu Modeling Islamic Economics and Finance Research: A Bibliometric Analysis

$\geq 0)$. VOS treats the Sij equation as a measurement on a ratio scale. The equations of $s_{i j}$ are usually calculated using the power of association defined in Equation 1 (for example Van Eck \& Waltman, 2007b). VOS determines the location of items in the map by minimizing.

$$
V\left(x_{i}, \ldots, x_{n}\right)=\sum_{i<j} s_{i j}\left\|x_{i}-x_{j}\right\|^{2}
$$

to be:

$$
\frac{2}{n(n-1)} \sum_{i<j}\left\|x_{i}-x_{j}\right\|=1
$$

There are two computer programs that have already implemented VOS mapping techniques. Both of these programs use the SMACOF algorithm variants mentioned above to minimize Equation 1 to Equation 2.

In addition to the mapping of Islamic economic and financial research that uses the mathematical model application approach, this study also tries to map the quality of these studies based on the Islamization framework proposed by Al-Attas. Two terms are used in mapping these studies; 1. Originative, meaning that the research carried out has carried out the process or stages of Islamization, 2. Adaptive, meaning that the research carried out only adopts an existing mathematical model with or without any process or stages of Islamization framework.

The basic idea of originative and adaptive has come from the fundamental issue, whereby Islamic economics and finance and conventional ones were departing from different worldviews. The difference between the theoretical foundation of the two might come up with a different conceptual outcome. The ethical foundation of Islamic economics will certainly recognize a specific scientific body of knowledge, including realistic model building (Hasan, 2016). Using the Islamization framework of Al-Attas (2014), any attempts that carry out the stage of isolation or elimination of foreign elements and key concepts from the body of existing knowledge, and infusing Islamic values and key concepts into it are considered as originative paper. According to Choudhury (2012), the originative process should be deductively carried out from the basic teaching of Islamic economy. He argued to totally reject the conventional neoclassicism and returning to an epistemological system premised on the Tawhidi worldview of unity of knowledge.

Whereas adaptive paper, could be and the two form, namely incorporatedadaptive and purely-adaptive papers. The former is characterized by papers that employing the existing conventional mathematical model with any attempts to critically evaluate the basic concept behind the model. Whereas the later, the papers only replicating the existing mathematical model and 
Rusydiana, Sanrego, \& Rahayu Modeling Islamic Economics and Finance Research: A Bibliometric Analysis

apply it as an analysis basis or framework to the practices of Islamic economic and finance.

\section{Results \& Analysis}

This study reviewed 100 studies with publishing from 1983 to 2019. During this period, research on mathematical models in Islamic economic and financial research indexed by Scopus occurred in 2011 as many as 9 published articles. At the beginning of the appearance of Scopus indexed papers on mathematical models in Islamic economic and financial research, from 2010 to 2014, only 1 to a maximum of 4 papers were published en masse. In 2010 and above compared to the previous year there was an increase in the number of Scopus indexed papers on mathematical models in Islamic economic and financial research. However, in 2012 and 2019 there was a large decrease in publication articles by 5 articles indexed by Scopus related to mathematical models in Islamic economic and financial research (Figure 1).

In addition, the reviewed papers are also classified based on the study location. In 100 papers, the most research on mathematical models in Islamic economic and financial research that was indexed by Scopus was conducted in Malaysia with 27 papers and the second highest in Indonesia with 21 papers. Other mathematical model studies in Islamic economic and financial research take place in Pakistan, Saudi Arabia, the United States, Oman, and Iran, with 15, 10, 9, 5, and 2 papers respectively (Table 1). This finding is relevant to the results of the publication of the Islamic Finance Development Report (2019) which put Malaysia, Indonesia, and Pakistan as the best countries based on Islamic finance knowledge indicators, especially the number of peer-reviewed articles and the number of research papers.

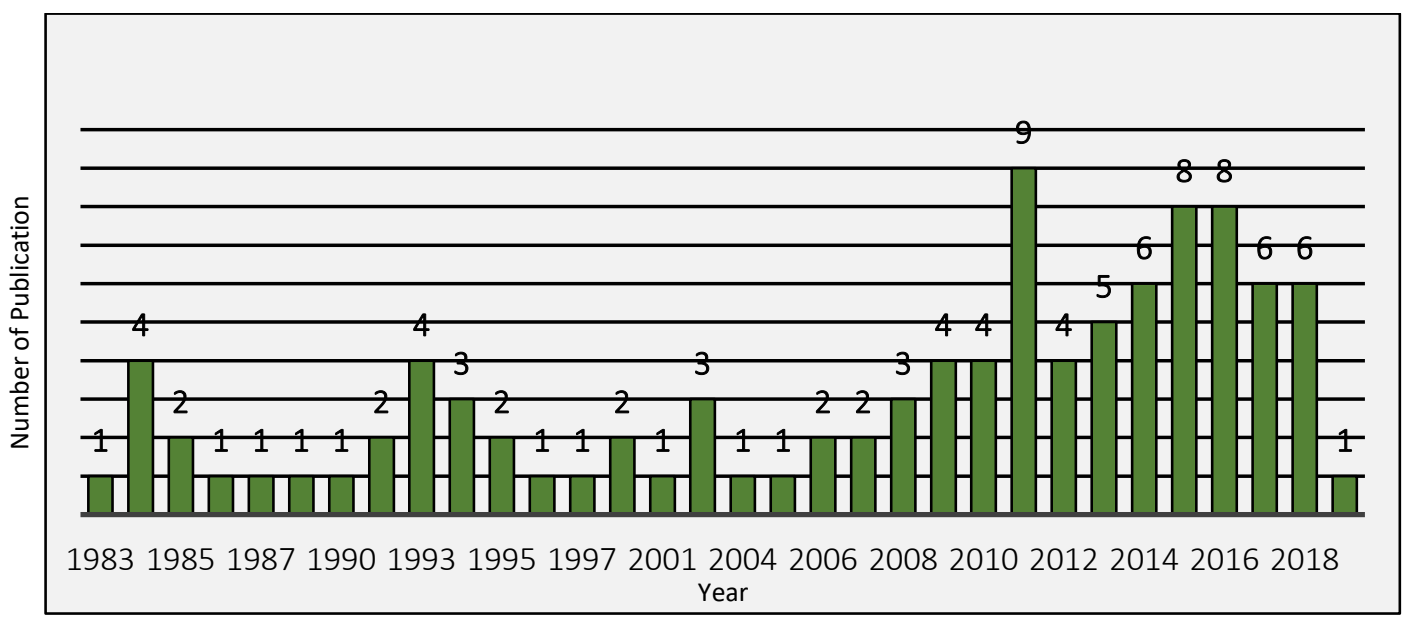

Figure 1. Classification of Publications by Year

Table 1. Classification of Publications by Case Study 
Rusydiana, Sanrego, \& Rahayu Modeling Islamic Economics and Finance Research: A Bibliometric Analysis

\begin{tabular}{clc|}
\hline No. & \multicolumn{1}{c}{ Country } & Number of Article \\
\hline 1. & Malaysia & 27 \\
2. & Indonesia & 21 \\
3. & Pakistan & 15 \\
4. & Kingdom of Saudi Arabia & 10 \\
5. & United States & 9 \\
6. & Oman & 5 \\
7. & Iran & 2 \\
8. & United Kingdom & 1 \\
9. & Italy & 1 \\
10. & Kuwait & 1 \\
11. & Morocoo & 1 \\
12. & Nigeria & 1 \\
13. & Netherlands & 1 \\
14. & Qatar & 1 \\
15. & Singapore & 1 \\
16. & Sudan & 1 \\
17. & Tunisia & 1 \\
18. & Australia & 1 \\
\hline & & Total
\end{tabular}

Classification of scientific articles based on the focus of research was also carried out in this study. Studies conducted cover various sectors such as Islamic banking, Islamic economics, Islamic monetary, Islamic capital markets, accounting, Islamic business and marketing, zakat, Islamic insurance (takaful), and endowments. Of the 100 studies, the focus of research on the most mathematical models is in the Islamic banking sector as many as 41 articles, followed by Islamic economics as many as 29 articles, followed by Islamic monetary and Islamic capital markets, each of which is 6 articles, followed by Islamic accounting, sharia business and marketing, Islamic insurance 4 each and 6 articles of social funds, namely zakat and endowments (waqf). (Figure 2). 
Rusydiana, Sanrego, \& Rahayu Modeling Islamic Economics and Finance Research: A Bibliometric Analysis

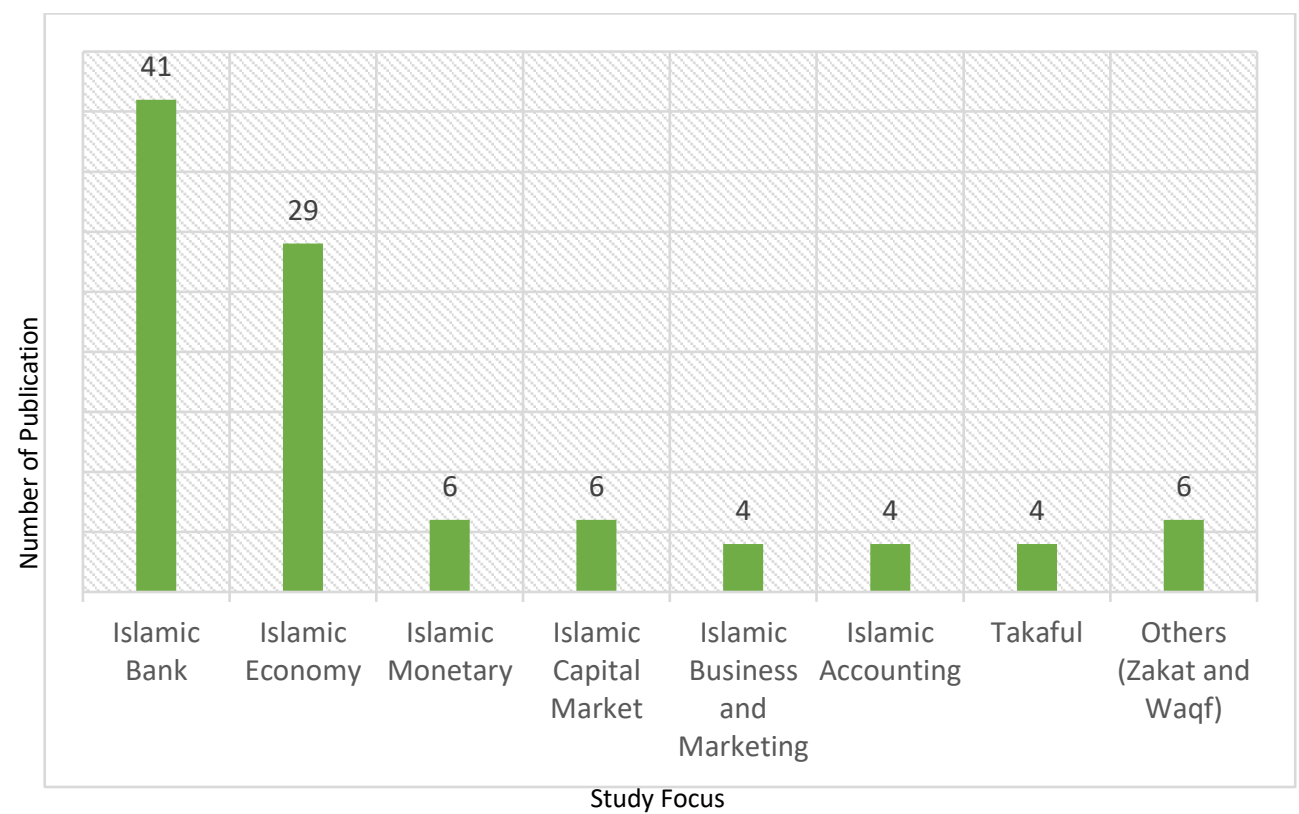

Figure 2. Classification of Publications by Study Focus

Classification of articles based on the number of citations is shown in Table 2 . There are 10 articles that have the most citations. The number of citations from each journal was obtained from Google Scholar on January 17, 2020. The article with the most citations was titled "Islamic interest-free banking, A theoretical analysis" which discusses mathematical models on Islamic banking with as many as 443 citations. Then the topic of many mathematical models used as citation is the topic of Islamic economics and followed by the topic of Islamic banking, and Islamic capital markets. The article with the 10 most citations is dominated by articles published under 2000.

Khan's article (1986) was the most cited because it's one of the first research uses mathematical models for Islamic banking at a time when other similar research still rarely use it. Khan criticizes Islamic economic academics for the absence of theories that strengthen the building of the Islamic economics system, especially in the research about Islamic banking and monetary compared to conventional banking. Meanwhile, Choudhury \& Hoque (2006) discussing on corporate governance related to Islamic socio-scientific epistemology. The results show that there is a big difference between the concept of Islamic corporate governance with mainstream literature. In its time, this paper was also one of the first to discuss mathematical modeling in the Islamic version of corporate governance theory proposals.

Another research that often used as a reference is an article written by Khan (1989). Slightly different from Khan's (1986) research article, this research tries to use mathematical modeling to compare Islamic financial systems based on a variable return scheme (VRS) with conventional systems based on 
Rusydiana, Sanrego, \& Rahayu Modeling Islamic Economics and Finance Research: A Bibliometric Analysis

Table 2. Classification of Publications by Citation

\begin{tabular}{cclc}
\hline No & $\begin{array}{c}\text { Year of } \\
\text { Publication }\end{array}$ & \multicolumn{1}{c}{ Title } & Citation \\
\hline 1 & 1986 & Islamic interest-free banking, A theoretical analysis & 443 \\
2 & 2006 & Corporate governance in Islamic perspective & 182 \\
3 & 1989 & Towards an Interest-Free Islamic Economic System & 179 \\
4 & 1984 & Macro Consumption Function in Islamic Framework & 91 \\
5 & 1983 & Portfolio management of Islamic banks, Certainty model & 65 \\
6 & 1994 & Comparative economics of some Islamic financing techniques & 63 \\
7 & 1993 & Equilibrium in a Non-Interest Open Economy & 59 \\
8 & 1996 & Cost of capital and investment in a non-interest economy & 52 \\
9 & 1984 & The Role of Sock Exchange in Islamic Economy & 42 \\
10 & 1993 & Equity capital, profit sharing contracts and investment, Theory and & 39 \\
& & evidence & \\
\hline
\end{tabular}

a fixed return scheme (FRS). Substantial results found in this article include mentioning that debt-based transactions (fixed) frequently used in financial transactions due to asymmetric information and high monitoring costs.

Classification of articles based on a methodological approach is shown in Figure 3. Based on 100 articles reviewed, it is divided into three categories, namely quantitative approaches, qualitative approaches, and mixed approaches, which are a combination of quantitative and qualitative. Articles that use a quantitative methodology approach as much as 32 or $32 \%$ and a qualitative approach amounting to 55. While those who use two methodological approaches at the same time (mixed) as many as 13. The majority of mathematical models are used to calculate the Profit-Loss Sharing (PLS) scheme which amounts to 16 publication articles and There are other economic models, namely profit sharing ratio (PSR), expectation spread (ES) model, and tax compliance behavior model. The mathematical model that plays a role in calculating a problem in the article being reviewed is the optimization theory.

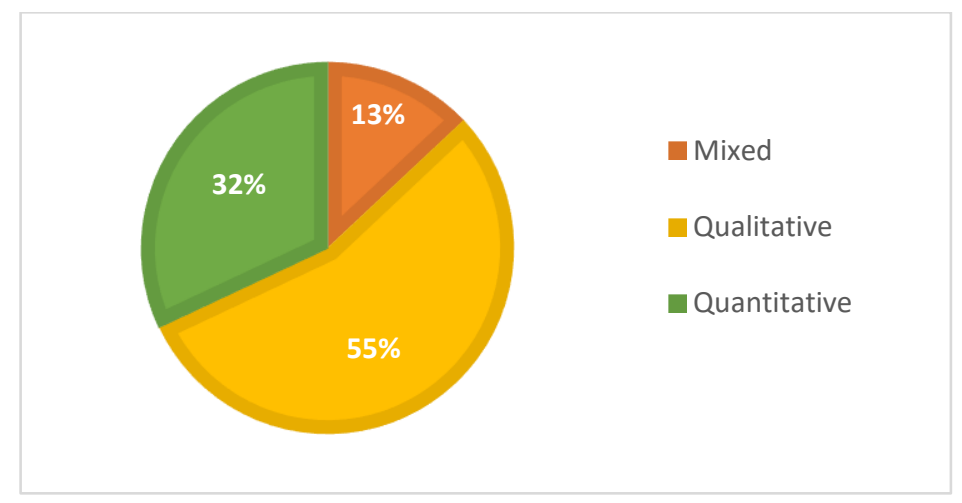

Figure 3. Classification of Publications by Methodology Approach 
Rusydiana, Sanrego, \& Rahayu Modeling Islamic Economics and Finance Research: A Bibliometric Analysis

\subsection{Map of Development Mathematical Model Research in Islamic Economic and Financial Research}

From the search results from the database 100 documents were then exported to the .txt format, inputted and analyzed with VOSViewer, the following results were obtained.

\subsubsection{Visualization of Network Co-Word Maps}

The results of the co-word map analysis of these keywords form the basis of mapping co-occurrence of important or unique terms contained in certain articles. Mapping is a process that allows one to recognize elements of knowledge and configuration, dynamics, interdependence, and their interactions. Knowledge mapping is used for the purposes of technology management, which includes the definition of research programs, decisions related to technology activities, the design of knowledge base structures, and the making of education and training programs. Related to bibliometrics, science mapping is a method of visualizing a science. This visualization is done by creating a landscape map that can display topics from science (Royani, et al., 2013). The results of the visualization of the co-word network map of mathematical model research in Islamic economic and financial research can be seen in Figure 4.

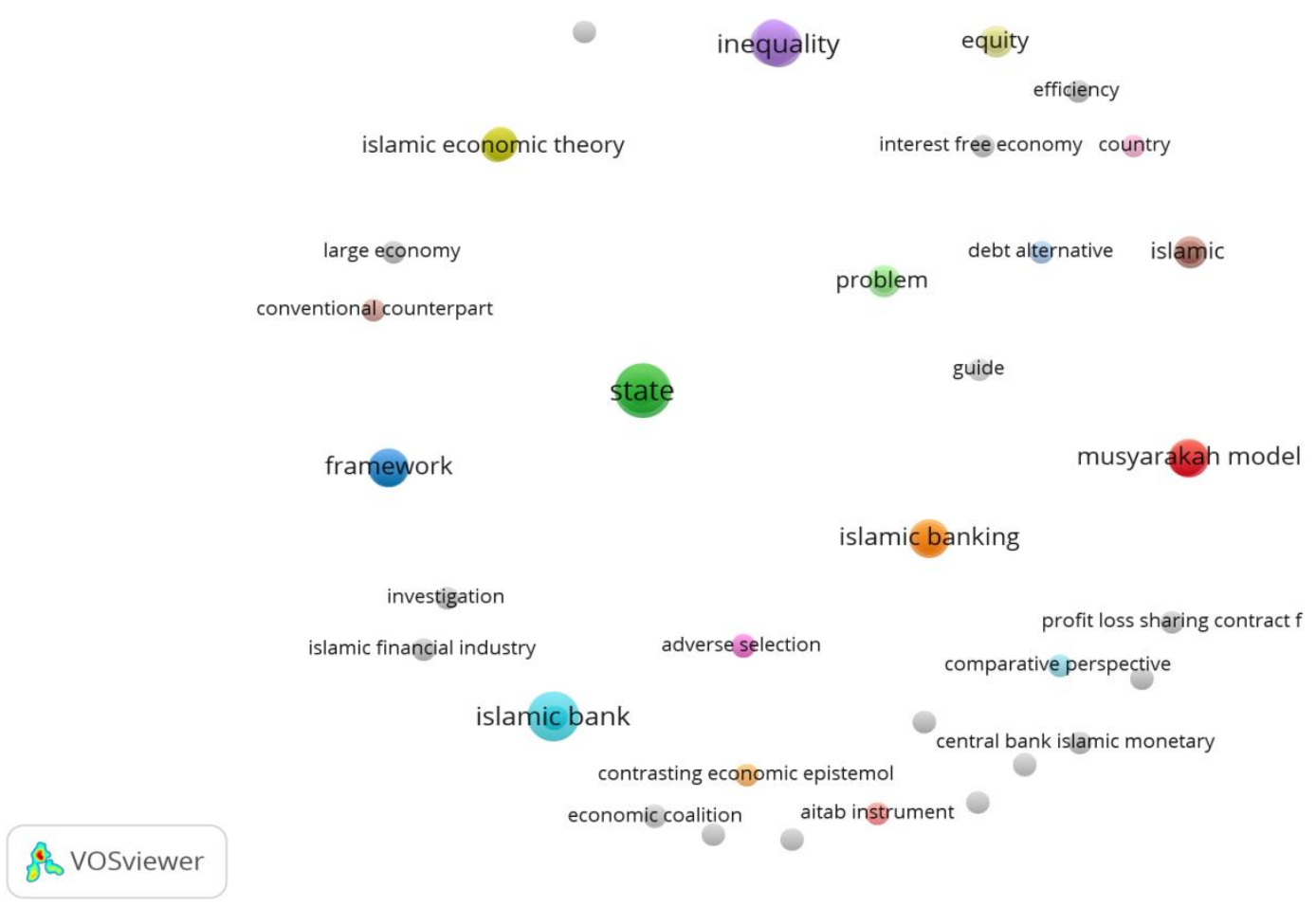

Figure 4. Network visualization of co-word maps 
Rusydiana, Sanrego, \& Rahayu Modeling Islamic Economics and Finance Research: A Bibliometric Analysis

Figure 4 shows that the map of the development of mathematical model research in Islamic economic and financial research is divided into 3 clusters as follows.

- Cluster 1 consists of 14 terms that is Islamic banking, musyarakah model, profit loss sharing (PLS) contract, comparative, perspective, central bank, Islamic monetary, aitab (al-ijarah tsumma al-bai') instrument, contrasting economic epistemology, economic coalition, adverse selection, Islamic bank, islamic financial industry, and investigation.

- Cluster 2 consists of 9 terms that is inequality, equity, efficiency, interest free economy, country, debt alternative, problem, Islamic, and guide.

- Cluster 3 consists of 5 terms that is Islamic economic theory, large economy, conventional counterpart, state, and framework.

Cluster 1 talks a lot about contracts and practices in Islamic banking, in particular the scheme and modeling of profit-loss sharing, both mudharabah, and musyarakah. Some modeling related to the PLS scheme, among others, was carried out by Bakhtiar et al. (2014), Halim (2013), Halim et al. (2016), Hasan (2010), Khaled \& Khandker (2015), Sugema et al. (2010), Sumarti \& Marendri (2017), Sumarti et al. (2015), Wahyudi \& Sakti (2016) and Wolf et al. (2018). Meanwhile, specifically, the mudharabah profit-sharing modeling has been carried out by Cahyandani et al. (2017), Jaffar \& Isa (2011), and Omar \& Jaffar (2016). The mathematical modeling research for the musharakah scheme has been investigated by Jaffar (2010), Jaffar et al. (2017), Mostafa et al. (2016), and Samson et al. (2008). Although the majority is applied in the banking industry, there are also those who make the takaful industry and the capital market as the object of study.

For example, relatively recent research, for example, Wolf et al. (2018) proposes a simple mathematical model that shows that the PLS contract can be used between mudharib and shahibul maal as potential alternative contracts for institutional debt financing. The important conclusion in his research is that the PLS financing scheme is an effective financing alternative, especially for medium-term and long-term loans, not short-term.

Cluster 2 in the visualization of co-word maps has a lot to do with the issue of fairness and injustice in financial transactions. The researchers consider that the Islamic-based transaction agreement especially profit sharing can answer this problem. The results of research conducted by researchers are at least able to prove in a mathematical formula that PLS-based financing is an alternative to ribawi-based debt financing. Islamic guidelines in dealing are considered capable of providing solutions to achieve justice and benefit between investors and business people. Some research that shows this can be found in studies conducted by Bashir et al. (1993), Hasan \& Siddiqui (1994), 
Rusydiana, Sanrego, \& Rahayu Modeling Islamic Economics and Finance Research: A Bibliometric Analysis

Hasan (2010), Khan (2015), and Tag el-Din (1992). Wolf et al. (2018) even prove that the PLS scheme can be an alternative to long-term interest-based loans in developing countries.

Meanwhile, cluster 3 in the co-word map visualization has a lot to do with theories that underlie Islamic financial and business transactions which are then reduced to mathematical models both macro as an economic system and micro as the form of Islamic economic and financial contracts as a comparison of conventional contracts in industry commercial banking in several countries. As has been shown previously, several Islamic banking scheme practices are found in countries such as Malaysia, Indonesia, Pakistan, and some GCC countries. An example is a research conducted by Abdullahi (2018), Kiaee et al. (2013), and Wahid (1985).

Indeed some terms and topics are among these three clusters. But in general, based on bibliometric calculations and mapping through VOSviewer, these three clusters are the largest and most structured. Some terms and topics are between the 2 clusters in which there is interconnectedness. Because in principle, in Islam and also Islamic finance and finance, there are no elements or variables that stand alone. The elements tend to relate to each other or are known as interdependence. The only one that is not affected is God (Allah) as an absolute independent variable (Choudhury, 1990, 2009, 2011).

\subsubsection{Visualization of Density Maps Co-Author}

The cluster density view, is an item (label) that is marked the same as the visible item. Each item point has a color that depends on the density of the item at the time. This identifies the color of the dots on the map depending on the number of items associated with other items. This section is very useful for obtaining an overview of the general structure of a bibliometric map by paying attention to the parts of the items that are considered important to be analyzed. Through this worksheet, we can interpret the authors who write the most publications. Visualization of the density map of co-authors of the development of mathematical model research in Islamic economic and financial research can be seen in Figure 5 . 
Rusydiana, Sanrego, \& Rahayu Modeling Islamic Economics and Finance Research: A Bibliometric Analysis

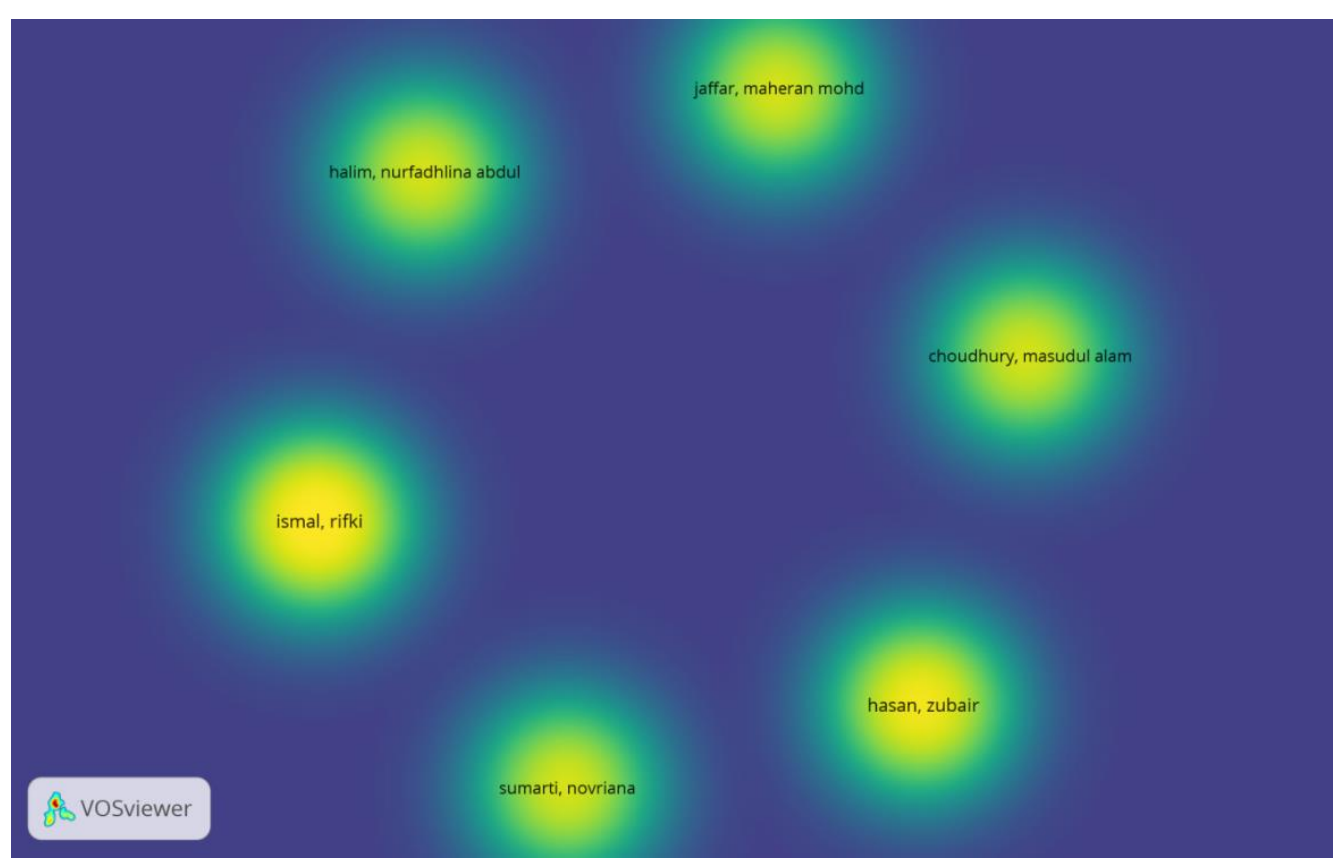

Figure 5. Visualization of density maps of co-author

Figure 5 shows the density map which is the result of an analysis using all the articles in the development of mathematical model research in Islamic economic and financial research, both related and unrelated. There are 6 cluster if sorted according to the author. The authors who wrote the most publications related to mathematical models in Islamic economic and financial research are Masudul Alam Choudhury, Rifki Ismal, Zubair Hasan, Novriana Sumarti, Nurfadhlina Abdul Halim and Maheran Mohd Jaffar.

Choudhury, Ismal, and Hasan, relatively researched under the name of one author and not a co-author. Meanwhile, the rest of it, tend to do research and publications in the form of writers along with other researchers. The majority of Choudhury's research is about meta-epistemology (Choudhury, 2011), Islamic criticism of the secular economy (Choudhury, 1990, 2009), and a concept known as Tauhidic String Relationship (TSR). Meanwhile, Ismal majored in researching mathematical models in financing portfolios in Islamic banks (Ismal, 2009, 2011b, 2012, 2014) and Islamic monetary themes in general (Ismal, 2011a, 2013). As for Hasan examines consumption related to Islamic economics, PLS, and the stability of the gold currency (Hasan, 2005, 2008, 2010).

Sumarti researched a lot of profit sharing contract schemes in Islamic banking and other transactions such as ijarah. Interestingly, the mathematical modeling methods used are relatively varied, such as the use of the SemiFuzzy Logic method (Sumarti \& Marendri, 2017), optimization techniques (Sumarti et al., 2014), and Data Simulation (Sumarti et al., 2015). This is understandable because of the background of researchers who are academics with a mathematician background. 
Rusydiana, Sanrego, \& Rahayu Modeling Islamic Economics and Finance Research: A Bibliometric Analysis

Halim and Jaffar generally researched and carried out mathematical modeling for PLS schemes both in banks and other financial institutions. The difference, Halim conducted a study on the application of the ijarah muntahiya bittamlik scheme or the AITAB contract (Halim et al. 2012; Halim et al., 2016; Halim, 2013) while Jaffar more demonstrated the PLS model in the musyarakah transaction agreement (Jaffar et al., 2017; Jaffar, 2010) and mudharabah (Omar \& Jaffar, 2016) or both (Jaffar \& Issa, 2011).

In conclusion, generally each researcher has a different tendency. Some prefer to write as a single writer, others write together with other researchers. Although the majority of the mathematical model stubs for the PLS scheme, there are variations in application both in banking and in other Islamic financial industries. Likewise, Islamic financial transaction agreements are objects, mudharabah, musyarakah, ijarah to the contract cooperation scheme 'Salam' as an object of the research. Interestingly enough, researchers who write a lot about the topic of mathematical modeling in Islamic economics and finance, at least have a background not only in economics, muamalah, or finance but also have the ability and background of qualified mathematics.

From the journal sources, the results of the visualization of the map overlay co-sources (publication sources) the development of research on mathematical models in Islamic economic and financial research are illustrated in Figure 6 below. Journals that look significant in terms of number of publications are Journal of King Abdul Aziz University (JKAU) - Islamic Economics. JKAU - Islamic Economics is the first professional journal in the field of Islamic economics. This journal was first published in 1983 under the title "Journal of Research in Islamic Economics" or JRIE. This journal has published several classic articles written by professionals in the field of Islamic economics. This journal has been indexed by Scopus starting in 2009.

Besides JKAU, it appears that the journals incorporated in Emerald international publication institutions are Humanomics (new name: International Journal of Ethics and Systems). Next is a journal based in the state of Pakistan, The Pakistan Development Review (PIDE). Outside the three journals above, there are Applied Mathematical Sciences, Contributions to Islamic Economics Theory, International Journal of Islamic and Middle Eastern Finance and Management, Procedia-Social and Behavioral Sciences, Studies in Economics and Finance, Advanced Science Letters, Managerial Finance, Journal of Banking and Finance, Social Epistemology and several other journals and publications.

Mathematical modeling research in Islamic economics and finance and Islamic economic themes, in general, have been widely published in many internationally reputed journals with various global indexes such as Scopus, Web of Science (WoS), ABDC, and other indexers. Likewise, well-known international publications such as Elsevier, Emerald, Springer, Sage, Taylor \& 
Rusydiana, Sanrego, \& Rahayu Modeling Islamic Economics and Finance Research: A Bibliometric Analysis

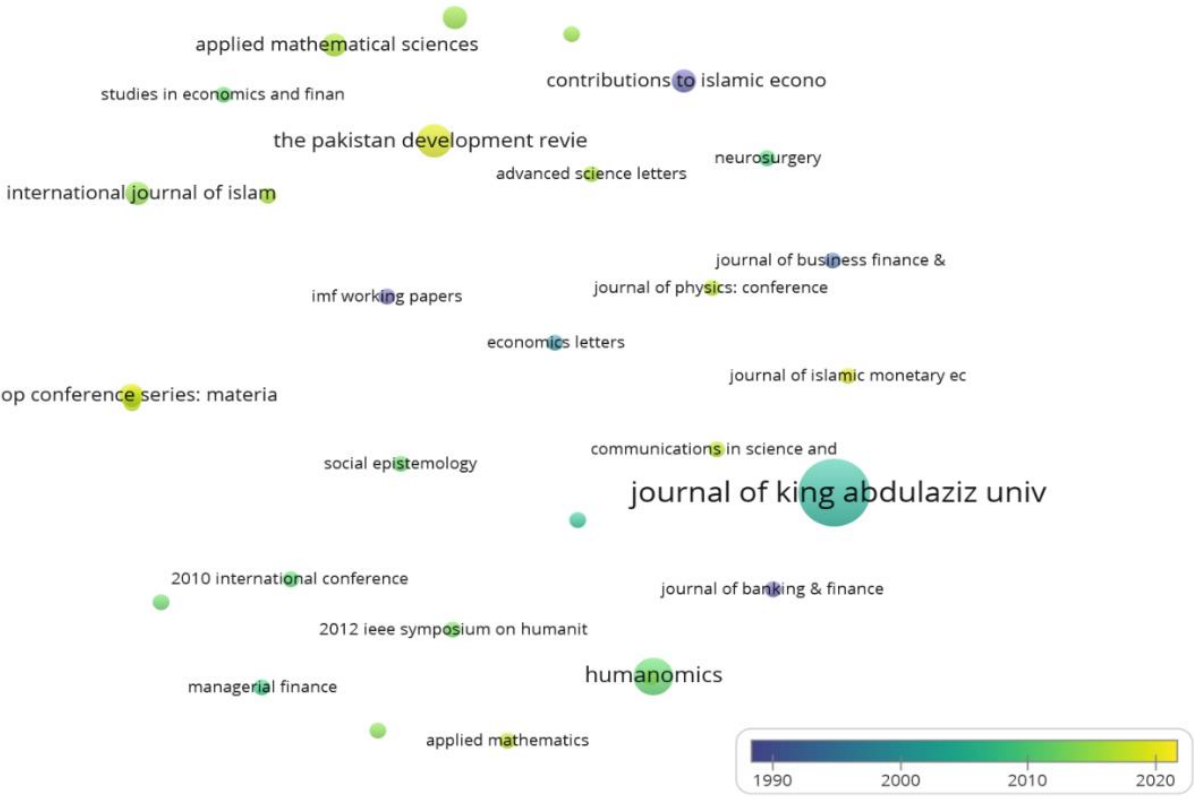

Figure 6. Visualization of map overlay co-sources (publication sources)

Francis, Inderscience to Wiley \& Blackwell. According to Rusydiana (2020), there are at least 119 Scopus indexed journals that publish articles on Islamic economics and finance globally. Issues related to Islamic financial economics have indeed become one of the interesting topics that are sought after in international reputable economic journals, in addition to other topics related to the theme of Sustainable Development Goals (SDGs), studies of Chinese economic development, and the halal industry.

Based on the grouping done by the author, in general, Islamic economic and financial modeling research is divided into 3 groups: (1) Originative, (2) Incorporated-Adaptive, (3) Purely-Adaptive. Some examples of research included in the first group (Originative) are research conducted by Choudhury (2014, 2012, 2011), Putri et al. (2018), Ahmad et al. (2011), and Hossain (2006). What Choudhury did, for example, he used a deductive approach in conducting his research. Choudhury proposed a concept known as Tawhidic String Relationship (TSR).

The example of research included in the second group (IncorporatedAdaptive) is research conducted by Ghazali et al. (2019), Khaldi \& Hamdouni (2018), Saputra et al. (2017), Sumarti et al. (2015), Bakhtiar et al. (2014), Ismal (2014), Halim et al. (2012) and Ismail \& Tohirin (2008). Meanwhile, some examples of the third group are those carried out by Derbali et al. (2017), Martan et al. (1984), Keen (2017), and Sapuan et al. (2015). In terms of numbers, research in the first group is relatively less compared to other research in the second and third groups. 
Rusydiana, Sanrego, \& Rahayu Modeling Islamic Economics and Finance Research: A Bibliometric Analysis

However, as a truly solid concept, basic research is needed that tries to formulate a more comprehensive and robust concept of Islamic economics and finance. According to Choudhury (2012), the originative process should be deductively carried out from the basic teaching of Islamic economy. He argued to totally reject the conventional neoclassicism and returning to an epistemological system premised on the Tawhidi worldview of unity of knowledge.

\section{Conclusion \& Recommendation}

\subsection{Conclusions}

Based on the results and discussion, the following conclusions are obtained. The number of publications of the development of mathematical model research results in Islamic economic and financial research indexed by Scopus and other reputable publication from 1983-2019 has increased since 2010 but is still small. Islamic banking and Islamic (macro) economics are the most research topics. Network visualization shows that the map of the development of mathematical model research in Islamic economic and financial research is divided into 3 clusters. Cluster 1 consists of 14 terms. Cluster 2 consists of 9 terms and cluster 3 consists of 5 terms. Cluster 1 talks a lot about contracts and practices in Islamic banking, in particular the scheme and modeling of profit loss sharing, both mudharabah, and musyarakah. Cluster 2 in the visualization of co-word maps has a lot to do with the issue of fairness and injustice in financial transactions. Meanwhile, cluster 3 in the coword map visualization has a lot to do with the theory underlying Islamic finance and business transactions. The authors who published the most research results of mathematical models in Islamic economic and financial research that were indexed by Scopus and other reputable journal were Masudul Alam Choudury, Rifki Ismail and Zubair Hasan. The name of the publication that mostly published the results of mathematical model research in Islamic economic and financial research that was indexed by Scopus was the Journal of King Abdulaziz University: Islamic Economics (JKAU-IE).

\subsection{Recommendations}

Based on the grouping by the author, in general, Islamic economic and financial modeling research is divided into 3 categories: (1) Originative, (2) Incorporated-Adaptive, (3) Purely-Adaptive. In terms of numbers, research in the first group is relatively less compared to research in the second and third groups. Despite the development of using mathematical model in those researches, the approach tends to be adaptive (inductive) from conventional models that already exist. A challenge to review the mainstream model need 
Rusydiana, Sanrego, \& Rahayu Modeling Islamic Economics and Finance Research: A Bibliometric Analysis

to be further critically reviewed. Hence, it is necessary for researcher to formulate a mathematical model with a deductive approach that is reduced from Islamic norms or ethics derived from the Alquran and Sunnah. For Islamic banking and finance practitioners, it is necessary to collaborate with academics to carry out economic and financial modeling that can be beneficial to stakeholders, especially bank customers. As for regulators, Islamic economic and financial modeling is expected to be an important input in the context of consideration in macro policymaking that can encourage Islamic banking and other Islamic financial economies to be better. Going forward, the clustering of these 3 categories is very open for discussion by Islamic economic and financial researchers in the world, with the hope that dialectics and the development of Islamic economic theory will not stop halfway. 
Rusydiana, Sanrego, \& Rahayu Modeling Islamic Economics and Finance Research: A Bibliometric Analysis

\section{References}

Abbas, M. (1987). Analysis of short-term asset concentration in Islamic banking. In IMF Working Paper.

Abdullah, N., Derus, A. M., \& Al-Malkawi, H. A. N. (2015). The effectiveness of zakat in alleviating poverty and inequalities: A measurement using a newly developed technique. Humanomics, 31(3), 314-329. https://doi.org/10.1108/H-02-2014-0016

Abdullahi, S. I. (2018). Contribution of mathematical models to Islamic economic theory: A survey. International Journal of Ethics and Systems, 34(2), 200-212. https://doi.org/10.1108/ijoes-09-2017-0129

Abusaud, M. (1993). The methodology of the Islamic behavioral sciences. The American Journal of Islamic Social Sciences, Vol. 10 No. 3, pp. 382-399

Ahmad, A. (1984). A macro model of distribution in an Islamic economy. Journal of Research Islamic Economics, 2(1), 3-18. https://doi.org/10.1007/978-1-349-07728-1_7

Ahmad, S., Nor, N. G., \& Daud, Z. (2011). Tax-based modeling of zakat compliance. Jurnal Ekonomi Malaysia, 45(1), 101-108.

Ahmid, A., \& Ondes, T. (2019). Bibliometric analysis of PhD dissertations written in Islamic banking and finance in the United Kingdom. Journal of Islamic Economics and Finance, 5(1), 63-91.

Al-Attas, Syed, Muhammad Naquib. (1995). Prolegomena to the Metaphysics of Islam: An Exposition of the Fundamental Elements of the Worldview of Islam. Kuala Lumpur: ISTAC.

Al-Attas, Syed, Muhammad Naquib. (2014). Islam and Secularism. Kuala Lumpur: IBFIM.

Bakhtiar, T., Sugema, I., \& Iqbal Irfany, M. (2014). Mathematical assessment on the robustness of PLS mechanism against adverse selection and moral hazard problems. Applied Mathematical Sciences, 8(13), 633-644. https://doi.org/10.12988/ams.2014.312674

Bashir, A., Darrat, A. F., \& Suliman, M. O. (1993). Equity capital, profit sharing contracts, and investment: Theory and evidence. Journal of Business Finance \& Accounting, 20(5), 639-651. https://doi.org/10.1111/j.14685957.1993.tb00281.x

Bashir, B, A. (1983). Portfolio management of Islamic banks "Certainty model". Journal of Banking and Finance, 7, 339-354. https://doi.org/10.1016/0378-4266(83)90043-2

Bendjilali, B. (1993). On muslim consumer behaviour: A mathematical set up. Journal of Islamic Economics, 3(1), 1-16.

Chiang, A.C. (2005). Fundamental methods of mathematical economics. McGraw-Hill International Editions. 
Rusydiana, Sanrego, \& Rahayu Modeling Islamic Economics and Finance Research: A Bibliometric Analysis

Choudhury, M. A. (2000). Regulation in the Islamic political economy: Comparative perspectives. Journal of King Abdulaziz University-Islamic Economics, 12(1), 21-51. https://doi.org/10.4197/islec.12-1.2

Choudhury, M.A. (1990). The humanomic structure of Islamic economic theory: a critical review of literature in normative and positive economics. Journal of King Abdulaziz University - Islamic Economics, Vol. 2 No. 1 , pp. 47-65.

Choudhury, M. A. (2009). Islamic critique and alternative to financial engineering issues. Journal of King Abdulaziz University, Islamic Economics, 22(2), 205-244. https://doi.org/10.4197/islec.22-2.11

Choudhury, M. A. (2011). A critique of economic theory and modeling: A meta-epistemological general-system model of Islamic economics. Social Epistemology, 25(4), 423-446. https://doi.org/10.1080/02691728.2011.604447

Choudhury, M. A. (2011). A development planning model and application using Islamic relational epistemology. Bulletin of Political Economy, 5(2).

Choudhury, M. A. (2012). The "imposibbility theorems" of Islamic economics. International Journal of Islamic and Middle Eastern Finance and Management, 5(3), 179-202. https://doi.org/10.1108/mf.2008.00934jaa.001

Choudhury, M. A. (2014). Social heteronomy and contrasting economic epistemology a mathematical approach. Procedia - Social and Behavioral Sciences, 140, 27-36. https://doi.org/10.1016/j.sbspro.2014.04.382

Choudhury, M. A., \& Hoque, M. Z. (2006). Corporate governance in Islamic perspective. Corporate Governance, 6(2), 116-128. https://doi.org/10.1108/14720700610655132

Derbali, A., El Khaldi, A., \& Jouini, F. (2017). Shariah-compliant capital asset pricing model: New mathematical modeling. Journal of Asset Management, 18(7), 527-537. https://doi.org/10.1057/s41260-0170051-x

el-Din, T., \& el-Din, S. (1997). Conventional growth policy and the forgotten potential resource: A case for the ethical economic resource. Journal of King Abdulaziz University-Islamic Economics, 9(1), 3-28. https://doi.org/10.4197/islec.9-1.1

el-Din, T., \& el-Din, S. (1992). Debt and equity in a primary financial market: A theory with Islamic implications. Journal of King Abdulaziz UniversityIslamic Economics, 4(1), 3-34. https://doi.org/Din, S10.4197/islec.4-1.1

Ghazali, P. L., Jaffar, S. A. S., Foziah, N. H. M., Tambi, A. M. A., Nawi, F. A. M., Mamat, M., ... S, M. M. (2019). The construction of a new mathematical model for Islamic home financing. Asian Academy of Management Journal, 24(1), 33-41. 
Rusydiana, Sanrego, \& Rahayu Modeling Islamic Economics and Finance Research: A Bibliometric Analysis

Halim, N. A. (2013). A validation of profit sharing ratio determination mathematical model for Islamic hire-purchase contract. Applied Mathematical Sciences, 7(41), 2035-2046. https://doi.org/10.12988/ams.2013.13183

Halim, N. A., Jaaman, S. H., Ismail, N., \& Ahmad, R. (2012). Profit sharing ratio modeling for Islamic hire-purchase contract: Robust optimization and chance constraint approach. In The 5th International Conference on Research and Education in Mathematics (Vol. 1450, pp. 55-60). https://doi.org/10.1063/1.4724117

Halim, N. A., Sharif, S. N. Bin, \& Jaaman-Sharman, S. H. (2016). Empirical testing of robust optimization profit sharing ratio with straight line depreciation in Aitab instrument. In AIP Conference Proceedings (Vol. 1750, pp. 1-6). https://doi.org/10.1063/1.4954538

Hamdani, S. N. H., Ahmad, E., \& Khalid, M. (2004). Study of philanthropic behaviour in divine economics framework. Pakistan Development Review, 43(4II), 875-894. https://doi.org/10.30541/v43i4iipp.875-894

Hasan, M. A., \& Siddiqui, A. N. (1994). Is equity financed budget deficit stable in an interest free economy? The Islamic Research and Training Institute, $1,1-14$.

Hasan, Z. (2005). Treatment of consumption in Islamic economics: An appraisal. Journal of King Abdulaziz University-Islamic Economics, 18(2), 29-46. https://doi.org/10.4197/islec.18-2.2

Hasan, Z. (2008). Ensuring exchange rate stability: Is return to gold (Dinar) possible? Journal of King Abdulaziz University-Islamic Economics, 21(1), 3-20. https://doi.org/10.4197/islec.21-1.1

Hasan, Z. (2010). Islamic banks: Profit sharing equity and credit control. Journal of King Abdulaziz University, Islamic Economics, 23(1), 131-147. https://doi.org/10.4197/Islec.23-1.5

Hossain, M. S. (2006). A development planning application of relational epistemology. Humanomics, 22(2), 98-112. https://doi.org/10.1108/08288660610669392

Ismail, A. G., \& Tohirin, A. (2008). Theoretical model of profit-loss sharing and investment.

Ismail, H. Bin. (2013). Observing the tabarru' rate in a family takaful. In 20th National Symposium on Mathematical Sciences (Vol. 1522, pp. 11521158). https://doi.org/10.1063/1.4801261

Ismal, R. (2009). Assessing moral hazard problem in murabahah financing. Journal of Islamic Economics, Banking and Finance, 5(2), 102-112.

Ismal, R. (2011a). Central bank Islamic monetary instruments: A theoretical approach. Studies in Economics and Finance, 28(1), 51-67. https://doi.org/10.1108/10867371111110552 
Rusydiana, Sanrego, \& Rahayu Modeling Islamic Economics and Finance Research: A Bibliometric Analysis

Ismal, R. (2011b). Depositors' withdrawal behavior in Islamic banking: Case of Indonesia. Humanomics, 27(1), 61-76. https://doi.org/10.1108/08288661111110187

Ismal, R. (2012). Formulating withdrawal risk and bankruptcy risk in Islamic banking. International Journal of Islamic and Middle Eastern Finance and Management, 5(1), 63-77. https://doi.org/10.1108/17538391211216848

Ismal, R. (2013). The Islamic gracious monetary instruments: A theoretical approach. Economic and Administrative Sciences, 29(1), 63-80.

Ismal, R. (2014). An optimal risk - return portfolio of Islamic banks. Humanomics, 30(4), 286-303. https://doi.org/10.1108/H-08-2013-0055

Ismal, R. (2014). Assessing the gold murabahah in Islamic banking. International Journal of Commerce and Management, 24(4), 367-382. https://doi.org/10.1108/IJCoMA-05-2012-0034

Ismal, R., \& Hidayat, S. E. (2016). A proposed formula for reserve requirement-financing to deposit ratio: The case of Islamic banking in Indonesia. In Macroprudential Regulation and Policy for the Islamic Financial Industry (pp. 121-131). https://doi.org/10.1007/978-3-31930445-8

Jaffar, M. M. (2010). New musharakah model in managing Islamic investment. ISRA International Journal of Islamic Finance, 2(2), 25-36.

Jaffar, M. M. (n.d.). Mathematical musyarakah model in managing Islamic investment between two parties using two profit sharing rates.

Jaffar, M. M. (2010). Mudharabah and musyarakah models of joint venture investments between two parties. In International Conference on Science and Social Research (CSSR 2010) (pp. 42-47). https://doi.org/10.1109/CSSR.2010.5773814

Jaffar, M. M., \& Mohd Isa, N. B. (2011). The net present value of mudharabah and musharakah models. In International Conference on Business, Engineering and Industrial Applications (pp. 30-34). https://doi.org/10.1109/ICBEIA.2011.5994253

Jaffar, M. M., Zain, S. M., \& Jemain, A. A. (2017). Diminishing musyarakah investment model based on equity. In AIP Conference Proceedings (Vol. 1905, pp. 1-6). https://doi.org/10.1063/1.5012143

Keen, S. (2017). Discounting for future costs and benefits: Economic versus social evaluation of projects. Journal of King Abdulaziz University, Islamic Economics, 30(1), 91-102. https://doi.org/10.4197/Islec.30-1.9

Khaldi, K., \& Hamdouni, A. (2018). Islamic financial intermediation compared to ribaoui financial intermediation: A theoretical and mathematical analysis. International Journal of Economics and Financial Issues, 8(3), 268-283. 
Rusydiana, Sanrego, \& Rahayu Modeling Islamic Economics and Finance Research: A Bibliometric Analysis

Khaled, S. A., \& Khandker, A. W. (2015). Profit-loss sharing contract formation under zero interest financial system. Journal of King Abdulaziz University, Islamic Economics, 28(2), 75-107. https://doi.org/10.4197/Islec.28-2.3

Khan, H. (2015). Some implications of debt versus equity-based financing in the backdrop of financial crises. Journal of King Abdulaziz University, Islamic Economics, 28(1), 165-180. https://doi.org/10.4197/Islec.28-1.7

Khan, M, F. (1984). Macro consumption function in an Islamic framework. Journal of Research Islamic Economics, 1(2), 3-25. https://doi.org/10.1007/978-1-349-07728-1_11

Khan, M. F. (1994). Comparative economics of some Islamic financing techniques. Islamic Economic Studies, 2(1), 35-68.

Khan, M. F. (2013). Theorizing Islamic economics: Search for a framework for Islamic economic analysis. Journal of King Abdulaziz University: Islamic Economics, 26(1), 209-242. https://doi.org/10.4197/Islec

Khan, M. S. (1986). Islamic interest-free banking: A theoretical analysis. Palgrave Macmillan Journals and International Monetary Fund, 33(1), 127.

Khan, W. M. (1989). Towards an interest-free Islamic economic system. Journal of King Abdulaziz University: Islamic Economics, 1, 3-38.

Kia, A. (2001). Speculative activities, efficiency and normative stock exchange. Journal of King Abdulaziz University-Islamic Economics, 13(1), 31-50. https://doi.org/10.4197/islec.13-1.2

Kiaee, H., Abrishami, H., \& Sobhani, H. (2013). Islamic banking performance vs its conventional counterpart : Using stochastic optimal control method. Journal of Islamic Economics Banking and Finance, 9(4), 58-76. https://doi.org/10.12816/0031375

Martan, S. S., Jabarti, A. A. H., Abdul-Fattah, A, F., \& Sofrata, H. (1984). Islamic vis-a-vis traditional aanking: A fuzzy-set approach, Journal of King Abdulaziz University: Islamic Economics, 2(1), 29-44.

Mirakhor, A. (1993). Equilibrium in a non-interest open economy. Journal of King Abdulaziz University: Islamic Economics, 5, 3-23. https://doi.org/10.5089/9781451944983.001

Mirakhor, A. (1996). Cost of capital and investment in a non-interest economy. Islamic Economic Studies, 4(1), 35-47.

Mirakhor, A., \& Krichene, N. (2014). Introductory Mathematics and Statistics for Islamic Finance. John Wiley \& Sons.

Mostafa, E. H., Abdenbi, E., \& Widiane, K. (2016). Modelling and assessment of product Musharaka Islamic financial risk. Journal of Applied Finance and Banking, 6(3), 157-167. Retrieved from http://0search.proquest.com.mylibrary.qu.edu.qa/abicomplete/docview/1789 066559/abstract/68A7D369932641DBPO/1\%5Cnhttp://0media.proquest.com.mylibrary.qu.edu.qa/media/pq/classic/doc/40570 
Rusydiana, Sanrego, \& Rahayu Modeling Islamic Economics and Finance Research: A Bibliometric Analysis

13761/fmt/pi/rep/NONE?hl=islamic\%2Cislamic\%2Cfinances\%2Cfinance \%2Cfinan

Olorogun, L. A. (2015). A proposed contribution model for general Islamic insurance industry. Islamic and Middle Eastern Finance and Management, 8(1), 114-131. https://doi.org/10.1108/IMEFM-04-20140032

Omar, A., \& Jaffar, M. M. (2016). The continuous model of stochastic mudharabah investment. Pertanika Journal of Social Sciences and Humanities, 24, 83-92.

Putri, L. W., Subhan, M., \& Rosha, M. (2018). Model matematika zakat dalam pengurangan kemiskinan. Journal of Mathematics, 1, 46-51.

Rahman, M., Isa, C.R., Tu, T.T., Sarker, M., \& Masud, M.A.K. (2020). A bibliometric analysis of socially responsible investment sukuk literature. Asian Journal of Sustainability and Social Responsibility, 5(7).

Rehman, S., \& Othman, R. (1994). Islamic economics literature: A bibliometric analysis. Intellectual Discourse, 2(2), 131-144.

Reuters, T. (2019). Islamic Finance Development Report 2019. Thomson Reuters, 1-44.

Rusydiana, A.S. (2020). Literature studies of Islamic economics and finance research in Scopus indexed journal Q1. Al-Muzaraah Journal, 8(1), 3956.

Samson, A. A., Jaffar, M. M., \& Ismail, N. (2008). Comparing mathematical models of Musyarakah Mutanaqisah with Bai bithaman ajil. In Simposium Kebanggan Sains Matematik Ke-16 (pp. 454-463).

Sapuan, N. M., Sanusi, N. A., Ismail, A. G., \& Wibowo, A. (2015). Optimal profit sharing contract and principal-agent value in Islamic bank. Advanced Science Letters, 21(6), 1837-1841. https://doi.org/10.1166/asl.2015.6132

Saputra, J., Kusairi, S., \& Sanusi, N. A. (2017). Modeling the premium and contract properties of family takaful (Islamic life insurance). Journal of King Abdulaziz University, Islamic Economics, 30(2), 135-157. https://doi.org/10.4197/Islec.30-2.12

Sugema, I., Bakhtiar, T., \& Effendi, J. (2009). Keunggulan sistem keuangan berbasis bagi hasil dan implikasinya pada distribusi pendapatan. Jurnal Keuangan Dan Perbankan, 13(3), 506-517. Retrieved from http://jurnal.unmer.ac.id/index.php/jkdp/article/view/1097

Sugema, I., Bakhtiar, T., \& Effendi, J. (2010). Interest versus profit-loss sharing credit contract: Effciency and welfare implications. International Research Journal of Finance and Economics, 45(45), 58-67.

Sumarti, N. (2018). A mathematics model for determinating the value of ijarah contract. In IOP Conference Series: Materials Science and Engineering (Vol. 288, pp. 1-6). https://doi.org/10.1088/1757-899X/288/1/012111 
Rusydiana, Sanrego, \& Rahayu Modeling Islamic Economics and Finance Research: A Bibliometric Analysis

Sumarti, N., \& Marendri, A. D. (2017). A mathematical model of PLS scheme of small investment for traditional market traders using the semi-fuzzy logic approach. Journal of Islamic Monetary Economics and Finance, 2(2), 173-192. https://doi.org/10.21098/jimf.v2i2.650

Sumarti, N., Fitriyani, V., \& Damayanti, M. (2014). A mathematical model of the profit-loss sharing (PLS) scheme. Procedia - Social and Behavioral Sciences, 115, 131-137. https://doi.org/10.1016/j.sbspro.2014.02.421

Sumarti, N., Sidarto, K. A., Syamsuddin, M., Mardiyyah, V. F., \& Rizal, A. (2015). Some problems on the making of mathematical modelling of a profitloss sharing scheme using data simulation. Mathematical and Fundamental Sciences, 47(1), 1-11. https://doi.org/10.5614/j.math.fund.sci.2015.47.1.1

Van Eck, N.J., \& Waltman, L. (2007a). VOS: A new method for visualizing similarities between objects. Proceedings of the 30th Annual Conference of the German Classification Society (pp. 299-306).

Van Eck, N.J., \& Waltman, L. (2007b). Bibliometric mapping of the computational intelligence field. International Journal of Uncertainty, Fuzziness and Knowledge-based Systems, 15(5), 625-645.

Van Eck, N.J., \& Waltman, L. (2010). Software survey: VOSviewer, a computer program for bibliometric mapping. Scientometrics, 84(2), 523-538.

Wahid, Abu, N, M. (1985). Islamic banks and a theory of optimal profit sharing. Islamic Studies, 24(3), 390-396.

Wahyudi, I., \& Sakti, A. (2016). Analyzing the profit-loss sharing contracts with markov model. Communications in Science and Technology, 1(2), 78-88. https://doi.org/10.21924/cst.1.2.2016.17

Wolf, F., Nabin, M. H., \& Bhattacharya, S. (2018). A mathematical demonstration of the viability of profit/loss sharing as a debt alternative in presence of market frictions. Journal of Emerging Market Finance, 17(3_suppl), 1-17. https://doi.org/10.1177/0972652718798075 
Rusydiana, Sanrego, \& Rahayu Modeling Islamic Economics and Finance Research:

A Bibliometric Analysis

\section{Appendix}

Table of Research Publications on Mathematical Models on Islamic Economics and Finance

\begin{tabular}{|c|c|c|}
\hline No & Name of Publication & $\begin{array}{c}\text { Number of } \\
\text { Articles }\end{array}$ \\
\hline \multicolumn{3}{|c|}{ Journal } \\
\hline 1. & Advance Science Letters & 1 \\
\hline 2. & ALQIMAH : The Journal of Management and Science & 1 \\
\hline 3. & Applied Mathematic Sciences & 2 \\
\hline 4. & Applied Mathematics & 1 \\
\hline 5. & Asian Academy of Management Journal & 1 \\
\hline 6. & Communications in Computer and Information Science & 1 \\
\hline 7. & Communications in Science and Technology & 1 \\
\hline 8. & Corporate Governance & 1 \\
\hline 9. & Economic and Administrative Sciences & 2 \\
\hline 10. & Humanomics & 5 \\
\hline 11. & International Journal of Commerce and Management & 1 \\
\hline 12. & International Journal of Economics and Financial Issues & 1 \\
\hline 13. & International Journal of Ethics and Systems & 1 \\
\hline 14. & International Journal of Islamic Finance & 1 \\
\hline 15. & International Monetary Fund & 1 \\
\hline 16. & International Research Journal of Finance and Economics & 1 \\
\hline 17. & Islamic Economic Studies & 2 \\
\hline 18. & Islamic Economics & 1 \\
\hline 19. & Islamic Middle Eastern Finance and Management & 3 \\
\hline 20. & Islamic Monetary Economics and Finance & 1 \\
\hline 21. & Journal of Applied Finance and Banking & 1 \\
\hline 22. & Journal of Asset Management & 1 \\
\hline 23. & Journal of Banking and Finance & 1 \\
\hline 24. & Journal of Business Finance \& Accounting & 1 \\
\hline 25. & Journal of Emerging Market Finance & 1 \\
\hline 26. & Journal of Islamic Economics & 1 \\
\hline 27. & Journal of Islamic Economics, Banking, and Finance & 2 \\
\hline 28. & Journal of King Abdulaziz University & 19 \\
\hline 29. & Journal of Mathematics & 1 \\
\hline 30. & Journal of Research Islamic Economics & 5 \\
\hline 31. & Jurnal Ekonomi Malaysia & 1 \\
\hline 32. & Jurnal Keuangan dan Perbankan & 1 \\
\hline 33. & Jurnal Teknologi & 1 \\
\hline 34. & Mathematical and Fundamental Sciences & 1 \\
\hline 35. & Pakistan Development Review & 7 \\
\hline
\end{tabular}


Rusydiana, Sanrego, \& Rahayu Modeling Islamic Economics and Finance Research: A Bibliometric Analysis

\begin{tabular}{|c|c|c|}
\hline 36. & Pertanika Journal of Social Sciences and Humanities & 2 \\
\hline 37. & Procedia-Social and Behavioral Sciences & 2 \\
\hline 38. & Social Epistemology & 1 \\
\hline 39. & Studies in Economics and Finance & 2 \\
\hline \multicolumn{3}{|c|}{ CONFERENCE } \\
\hline 1. & 8th International Conference on Islamic Economics and Finance & 1 \\
\hline 2. & IOP Conference Series: Materials Science and Engineering & 3 \\
\hline 3. & $\begin{array}{l}\text { The 5th International Conference on Research and Education in } \\
\text { Mathematics }\end{array}$ & 1 \\
\hline 4. & AIP Conference Proceedings & 2 \\
\hline 5. & International Conference on Science and Social Research (CSSR 2010) & 1 \\
\hline 6. & $\begin{array}{l}\text { International Conference on Business, Engineering and Industrial } \\
\text { Applications }\end{array}$ & 1 \\
\hline 7. & $\begin{array}{l}\text { Conjunction with 4th International Postgraduate Conference on } \\
\text { Science and Mathematics }\end{array}$ & 1 \\
\hline 8. & Simposium Kebanggan Sains Matematik Ke-16 & 1 \\
\hline 9. & 20th National Symposium on Mathematical Sciences & 1 \\
\hline 10. & $\begin{array}{l}\text { International Seminar on Macroeconomics from Islamic } \\
\text { Perspective:Theory and Contemporary Issues }\end{array}$ & 1 \\
\hline 11. & $\begin{array}{l}\text { IEEE Symposium on Humanities, Science and Engineering Research } \\
\text { Analysis }\end{array}$ & 1 \\
\hline \multicolumn{3}{|c|}{ Working Paper } \\
\hline 1. & IMF Working Paper & 1 \\
\hline 2. & Islamic Economics and Finance No. 0805 & 1 \\
\hline \multicolumn{3}{|c|}{ Magazine Article } \\
\hline 1. & $\begin{array}{l}\text { Bulletin of Political Economy : A Development Planning Model and } \\
\text { Application using Islamic Relational Epistemology }\end{array}$ & 1 \\
\hline \multicolumn{3}{|c|}{ Book \& Book Section } \\
\hline 1. & Introductory Mathematics and Statistics for Islamic Finance & 1 \\
\hline 2. & $\begin{array}{l}\text { Macroprudential Regulation and Policy for the Islamic Financial } \\
\text { Industry }\end{array}$ & 1 \\
\hline 3. & IDB:IRTI Book No.3 & 1 \\
\hline & TOTAL & 100 \\
\hline
\end{tabular}


Rusydiana, Sanrego, \& Rahayu Modeling Islamic Economics and Finance Research: A Bibliometric Analysis

This page is intentionally left blank.

International Journal of Islamic Economics and Finance (IJIEF), 4(1), 149-176 | 176 